\title{
APPLICATION OF ACID WHEY AND SET MILK TO MARINATE BEEF WITH REFERENCE TO QUALITY PARAMETERS AND PRODUCT SAFETY*
}

\author{
Karolina M. Wójciak ${ }^{1 凶}$, Paweł Krajmas ${ }^{2}$, Elżbieta Solska ${ }^{1}$, Zbigniew J. Dolatowski ${ }^{1}$ \\ ${ }^{1}$ Department of Meat Technology and Food Quality, University of Life Sciences in Lublin \\ Skromna 8 Street, 20-704 Lublin, Poland \\ 2“JK" Sp. z o.o. Meat Manufactur "Jasiołka”, Dukla, Poland
}

\begin{abstract}
Background. The aim of the study was to evaluate the potential of acid whey and set milk as a marinade in the traditional production of fermented eye round.

Material and methods. Studies involved assaying $\mathrm{pH}$ value, water activity $\left(\mathrm{a}_{\mathrm{w}}\right)$, oxidation-reduction potential and TBARS value, colour parameters in CIE system $\left(\mathrm{L}^{*}, \mathrm{a}^{*}, \mathrm{~b}^{*}\right)$, assaying the number of lactic acid bacteria and certain pathogenic bacteria after ripening process and after 60-day storing in cold storage. Sensory analysis and analysis of the fatty acids profile were performed after completion of the ripening process. Results. Analysis of $\mathrm{pH}$ value in the products revealed that application of acid whey to marinate beef resulted in increased acidity of ripening eye round (5.14). The highest value of the colour parameter $\mathrm{a}^{*}$ after ripening process and during storage was observed in sample AW (12.76 and 10.07 respectively), the lowest on the other hand was observed in sample SM (10.06 and 7.88 respectively). The content of polyunsaturated fatty acids (PUFA) was higher in eye round marinated in acid whey by approx. $4 \%$ in comparison to other samples. Conclusion. Application of acid whey to marinade beef resulted in increased share of red colour in general colour tone as well as increased oxidative stability of the product during storage. It also increased the content of polyunsaturated fatty acids (PUFA) in the product. All model products had high content of lactic acid bacteria and there were no pathogenic bacteria such as: L. monocytogenes, Y. enterocolitica, S. aureus, Clostridium sp.
\end{abstract}

Key words: acid whey, beef, organic meat products

\section{INTRODUCTION}

Raw ripened meat products have become one of the more important components of the human diet in Central Europe, including Poland. The regional products of Italy, Spain, Portugal, France, German, Czech and recently even the Poland are very well described in scientific literature for the development of enzymatic and ageing processes dependent on salt concentration, time of ripening and microflora activity (Laureati et al., 2014; Węsierska et al., 2013a). The quality and safety of fermented meat products depends on the

\footnotetext{
*The study was performed as part of own research project No. RR-re-029-10-3040/10 financed by the Minister of Agriculture and Rural Development.
} 
direction of endo- and exogenous biochemical process, which take place during the ripening process and storing. Recipe, climate conditions, microflora are different in different regions and lands, where products are manufactured (Węsierska et al., 2013a; 2013b). The production of uncured fermented beef product relies on traditional techniques, and processing is greatly affected by the habits of artisans, raw materials and regions of Poland. However, the quality and safety of such products are related with the microflora of the fermented product (Sip et al., 2012). It is difficult to obtain uncured fermented beef product of a standard and high quality, mostly due to different technology, hygienic and microbiological conditions (Laureati et al., 2014; Węsierska et al., 2014). Traditional fermented beef products are frequently produced without use of starter cultures, only by autochthonous microbiota present in raw beef and the environment (Sip et al., 2012). In one of the mountainous regions of Poland (Podkarpacie), acid whey and set milk obtained from raw (unpasteurised) milk during natural fermentation (without addition of starter cultures) are used as marinade in the manufacturing process of raw-ripening beef products. Podkarpacie represents one of the few regions in Poland where the tradition of producing fermented, cured or uncured fermented and heat-treated meats and sausages is still observed but the products are known only to Podkarpacie residents. There are no studies on traditional uncured fermented beef products from the piedmont region of Poland (Podkarpacie).

The objectives of the present work were:

a. to evaluate the potential of acid whey and set milk as a marinade in the traditional production of fermented eye round

b. to analyse the influence of two kind of marinade: set milk and acid whey on the quality parameters of the product

c. to assess the stability of the product by determining microbial count, colour, lipid oxidation during refrigerated storage at $4^{\circ} \mathrm{C}$.

\section{MATERIAL AND METHODS}

\section{Experimental procedures}

The raw material for the production of a ripening eye round was cooled $\left(24 \mathrm{~h}, 2-4^{\circ} \mathrm{C}\right)$ semimembranous muscle (Lat. musculus semimembranosus) obtained from
Limousin cattle with body weight of approx. 400-450 $\mathrm{kg}$ which were bred in the organic farming system.

Acid whey was obtained from local farm which organically breeds dairy cattle and is a producer of dairy organic products. Fresh unpasteurized milk underwent the natural milk fermentation process. Afterwards, it was heated to the temperature of approx. $40^{\circ} \mathrm{C}$. After acid coagulation of milk, protein was completed, and whey was separated from the curd.

After 48 hours since the slaughter, semimembranous muscle was marinated in acid whey or set milk for 48 hours at a temperature of $2^{\circ} \mathrm{C}$. Afterwards, sea salt was added to meat in amount of $3.0 \%$ in relation to the meat mass. Products were subjected to 21-day ripening process at a temperature of $16^{\circ} \mathrm{C}$ and relative humidity of $75-85 \%$. After ripening, beef was smoked with a cold smoke (approx. $26^{\circ} \mathrm{C}$ ) and afterwards it was vacuum-packed and stored at a temperature of $4^{\circ} \mathrm{C}$. Products were tested after the ripening process (21 days) and after cold storage. The fermented beef production process was performed in "JK" Sp. z o.o. Meat Manufactur "Jasiołka" in Dukla (Podkarpacie).

The following experimental variants $(25 \mathrm{~kg}$ for each sample) have been prepared:

- $\mathrm{C}$ - control ripening beef with additional of $3.0 \%$ of sea salt

- $\mathrm{AW}$ - ripening beef marinated in acid whey for $48 \mathrm{~h}$, with additional of $3.0 \%$ of sea salt

- $\mathrm{SM}$ - ripening beef marinated in set milk for $48 \mathrm{~h}$, with additional of $3.0 \%$ of sea salt.

\section{Analysis of samples}

$\mathrm{pH}$ value and water activity deterioration. Acidity was determined by measuring $\mathrm{pH}$ value with use of CPC 501 digital pH/conductivity meter (Elmetron, Zabrze, Poland) and ERH-111-type combined electrode (Hydromet, Gliwice, Poland). The analysis of the water activity $\left(\mathrm{a}_{\mathrm{w}}\right)$ in the product was conducted at a temperature of $20^{\circ} \mathrm{C}$ with the use of LabMaster device (Novasina AG, Lachen, Switzerland).

Oxidation-reduction potential. Oxidation-reduction potential was determined with use of ERPt-13-type platinum combined electrode with use of digital CPC$501 \mathrm{pH}$ and conductivity meter (Elmetron, Zabrze, Poland) on the basis of the methods described by Ahn and Nam (2003). 
TBARS value. TBARS was determined on the basis of methods described by Pikul et al. (1989). Intensity of pink colour created due to reaction of fat oxygenation products with 2-thiobarbituric acid was measured with use of Nikole Evolution 300 spectrophotometer (Thermo Elektron Corporation) at a wavelength of $532 \mathrm{~nm}$.

Colour. Measurement of colour parameters in CIE L* $a^{*} b^{*}$ system was performed with the reflection method with the use of 8200 Series (X-Rite) spherical spectrophotometer. Measurements were conducted with regard to shine (SPIN) in the measurement range from 360 to $740 \mathrm{~nm}$ with use of typical D65 light source and typical colourimetric observer with vision field of $10^{\circ}$ (Hunt, 1987).

Microbial analysis. LAB was assayed according to PN ISO 15214:2002 and selected pathogenic bacteria were assayed as well. Assay of $S$. aureus was performed on the basis of PN ISO 6888-2:2001/A1:2004 whereas L. monocytogenes on the basis of Rapid Lmono method developed by Biorad company (QMP-504-EC-27-51-1), Clostridium sp., Yersinia enterocolitica acc. to Nakajima et al. (1991). The results are reported as colony forming units per gram of product $[\mathrm{cfu} / \mathrm{g}]$.

Fatty acids. Fat from products was obtained with the use of Folch et al. (1957) method. Fatty acid methyl esters were prepared according to the method using methanolic potassium hydroxide solution (PN-ISO 5509:1996). Separation of fatty acid methyl esters from obtained fat was conducted with gas chromatography method and with the use of Varian 450-GC gas chromatograph with FID detector and recorder (PN-ISO 5508:1996). Assays were made in the following conditions: 30 meter long Select ${ }^{\mathrm{TM}}$ Biodiesel for FAME capillary product with diameter of $0.32 \mathrm{~mm}$, Select ${ }^{\mathrm{TM}}$ Biodiesel for FAME Fused Silica stationary phase, temperature programme of the column oven: $200^{\circ} \mathrm{C}$ for 10 minutes, $200-240^{\circ} \mathrm{C}\left(3^{\circ} \mathrm{C} / \mathrm{min}\right), 240^{\circ} \mathrm{C}$ for 4.67 minutes, temperature of the detector and injector -300 and $250^{\circ} \mathrm{C}$ respectively, carrier gas - helium, flow $2.5 \mathrm{ml} / \mathrm{min}$, injection type: Split/Splitless 0-1.5 min, Split ratio 50, 1.5-28 min Split ratio 10. Identification of fatty acids peaks was conducted by comparison with the retention time of the patterns of fatty acid methyl esters. Percentage share of fatty acids was calculated on the basis of integration of peak surface performed by computer system of the chromatographic set and was expressed as percentage share of each fatty acid in relation to general amount of fatty acids $[\% \mathrm{~m} / \mathrm{m}]$. All assays were performed in two parallel repetitions.

Sensory analysis. The method of Quantitative Descriptive Analysis (QDA) was used for sensory evaluation (PN-ISO 13299:1998; PN-ISO 11035:1999). QDA analysis was performed by an evaluating team consisting of 8 people who were trained according to the requirements of PN ISO standard PN-ISO 8586$-2: 1996$. The following defining features were selected and defined: four features of smell (typical for raw meat, acid, rancid, other/out of the list), six features of flavour (typical for raw meat, sour, bitter, acid, rancid, other/out of the list), two features of the texture (juiciness, hardness). The evaluation included also general quality of the product. The team recorded the answers on the unstructured assessment scale $(0-10$ a.u.) with markings on both of its poles: evaluation of smell and flavour ("imperceptible" - "very intense"), juiciness evaluation ("dry" - "very juicy"), hardness evaluation ("very hard" - "tender").

\section{RESULTS AND DISCUSSION}

Analysis of $\mathrm{pH}$ value revealed that immediately after completion of the ripening process the highest $\mathrm{pH}$ value was observed in the control sample (5.37) and the lowest in the sample marinated in acid whey (5.14). The higher acidity of the control sample is confirmed by the results of sensory evaluation, in which the greatest intensity of acid smell and flavour of 2.5 c.u. and 3.4 c.u. was observed in eye round marinated in acid whey due to fermentation activity of Lactobacillus bacteria (Table 4). Increased $\mathrm{pH}$ after 60 days of storing was observed in all samples, except the sample with whey in which the $\mathrm{pH}$ remain at the constant level (5.19). According to Kaban (2013), the increase in $\mathrm{pH}$ results from proteolysis occurring in ripening products. This, however, is not confirmed by the results of sensory analysis which indicate lack of bitter taste due to bitter peptides formed as a result of protein proteolysis. Similar pH was obtained by other authors (Gök et al., 2008; Kaban, 2013; Kaban and Kaya, 2006) 
in Pastirma and dried beef - Cecina de León (Rubio et al. 2006). The $\mathrm{pH}$ value of the products in cited studies ranged from 5.69 to 6.20 (Gök et al. 2008; Kaban, 2013; Kaban and Kaya, 2006; Rubio et al. 2006).

The analysis of the water activity $\left(\mathrm{a}_{\mathrm{w}}\right)$ in ripening beef revealed that immediately after ripening process the lowest value of $\mathrm{a}_{\mathrm{w}}(0.854)$ was observed in the sample with set milk, whereas the control sample had the highest value (0.856). After 60-day period of cold storage, decrease in water activity by approx. 0.02 units was observed in all samples. Kaban (2013) as well as Kaban and Kaya (2006) also noted similar water activity ranging from 0.85 to 0.90 in fermented beef product.

All studied versions of beef analysed after the ripening process revealed close values of redox potential from 290.7 to $296.87 \mathrm{mV}$. During cold storage, the authors observed the increase of the oxidation-reduction potential in all tested samples by $71.03 \mathrm{mV}, 60.8 \mathrm{mV}$, $39.63 \mathrm{mV}$ in sample C, AW and SM respectively.

Physical, chemical and biological changes occur in lipids. Endogenous and exogenous enzymatic hydrolysis as well as autoxidation constitute two highly undesirable directions of changes of lipids which may occur in the preliminary ripening stage (production) and post-manufacturing stage (storage). The analysis of TBARS examined in eye round immediately after ripening revealed that the lowest value of secondary oxidation products was present in the sample marinated in acid whey (AW) $1.40 \mathrm{mg} / \mathrm{kg}$, the highest on the other hand in the sample marinated in set milk (SM)
$1.58 \mathrm{mg} / \mathrm{kg}$. The value of TBARS increased after storage in samples $C$ and SM respectively by 0.11 and 0.25 $\mathrm{mg} / \mathrm{kg}$, whereas in the sample marinated in acid whey (AW) it remained on the same level. Similar values of TBARS within 0.86 and $1.54 \mathrm{mg} / \mathrm{kg}$ were observed by Gök et al. (2008) in Pastirma airtight packed and stored for 60 days.

Oxidation processes in meat product did not significantly affect the intensity of rancid taste and smell (Fig. 1). This is confirmed by the results of studies conducted by Chouliar et al. (2008), who did not observe correlation between content of secondary oxidation products (if they were lower than $3.0 \mathrm{mg} / \mathrm{kg}$ ) and presence of rancid smell and taste (Chouliar et al., 2008). TBARS in all tested products did not exceed the threshold value $(3.0 \mathrm{mg} / \mathrm{kg})$ which indicated high oxidative stability of the system.

Colour is a significant factor of the quality of beef products in the view of the consumer. If it is not approved by the purchaser, all remaining qualitative features of the product which are visually assessed loose its meaning. In the case of fermented products, colour may be affected by numerous factors such as: chemical form and myoglobin concentration, product composition, $\mathrm{pH}$, redox potential, lipid oxidation, additives used, availability of light, storage temperature, bacteria growth (Kołczak, 2009). Colour lightness of the product examined directly after 21 days of ripening did not depend on the type of technological procedures. After 60-day storage period, the colour of

Table 1. $\mathrm{pH}$ value, water activity, oxidation-reduction potential and TBARS value in ripening eye round examined during storage period (60 days)

\begin{tabular}{cccccc}
\hline Sample & $\begin{array}{c}\text { Time } \\
\text { days }\end{array}$ & $\mathrm{pH}$ & $\mathrm{a}_{\mathrm{w}}$ & ORP, $\mathrm{mV}$ & $\begin{array}{c}\text { TBARS } \\
\mathrm{mg} / \mathrm{kg}\end{array}$ \\
\hline $\mathrm{C}$ & 0 & $5.37 \pm 0.01$ & $0.856 \pm 0.001$ & $292.30 \pm 1.13$ & $1.46 \pm 0.14$ \\
& 60 & $5.44 \pm 0.01$ & $0.833 \pm 0.001$ & $363.33 \pm 5.88$ & $1.57 \pm 0.15$ \\
$\mathrm{AW}$ & 0 & $5.14 \pm 0.01$ & $0.860 \pm 0.002$ & $296.87 \pm 1.17$ & $1.40 \pm 0.25$ \\
& 60 & $5.19 \pm 0.02$ & $0.851 \pm 0.001$ & $357.67 \pm 3.86$ & $1.65 \pm 0.08$ \\
$\mathrm{SM}$ & 0 & $5.16 \pm 0.02$ & $0.854 \pm 0.001$ & $290.07 \pm 1.97$ & $1.58 \pm 0.06$ \\
& 60 & $5.62 \pm 0.02$ & $0.837 \pm 0.002$ & $329.70 \pm 0.70$ & $1.35 \pm 0.18$ \\
\hline
\end{tabular}

Explanatory notes: $\mathrm{C}$ - control with sea salt (3\%), AW - experimental with acid whey and sea salt (3\%), SM - experimental with set milk and sea salt (3\%), mean value \pm standard error. 
Wójciak, K. M., Krajmas, P., Solska, E., Dolatowski, Z. J. (2015). Application of acid whey and set milk to marinate beef with reference to quality parameters and product safety. Acta Sci. Pol. Technol. Aliment., 14(4), 293-302. DOI: 10.17306/J.AFS.2015.4.30

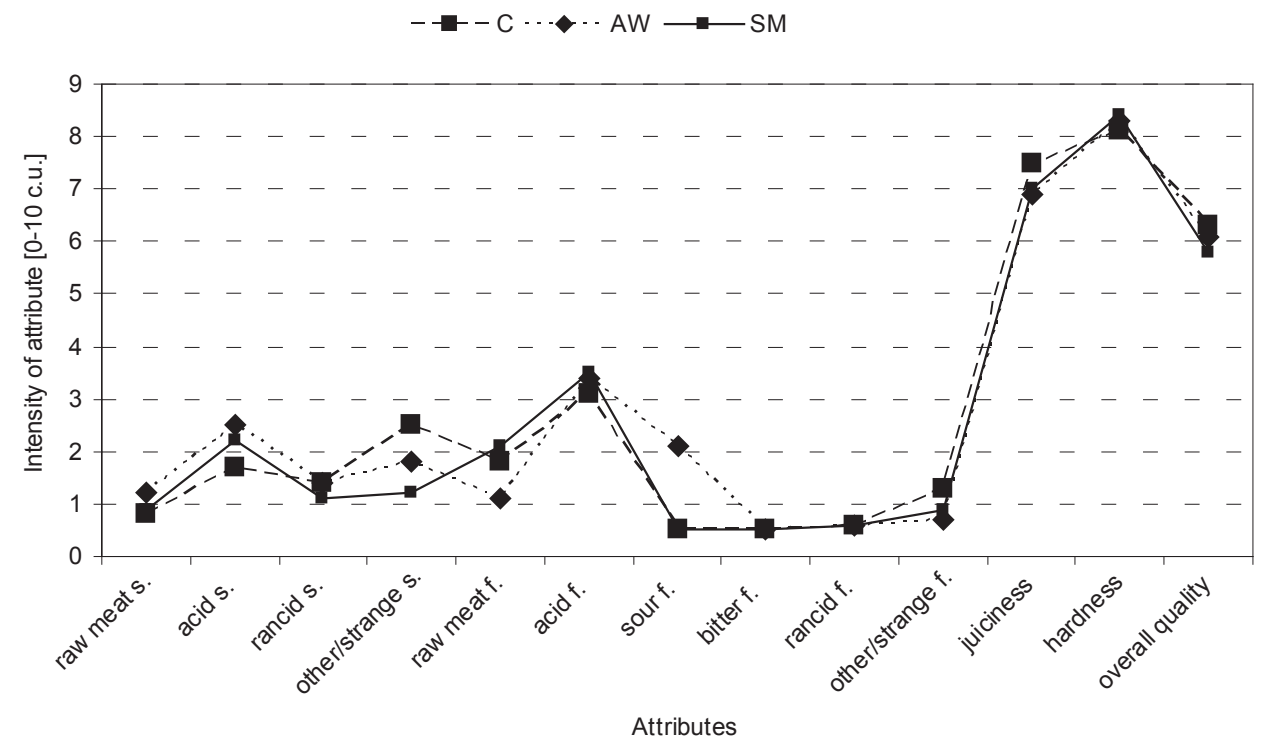

Fig. 1. Sensory score results of ripening eye examined after the end of productive ripening process. Explanatory notes: Smell: raw meat s. - typical of raw meat; acid s. - basic quality of smell; rancid s. - off-flavour associated with changes in fat oxidation; other/strange s. - other sensation, out of the list. Flavour: raw meat f. - typical of raw meat; acid f. - basic quality of taste; sour f. - basic quality of taste; bitter f. - basic quality of taste; rancid f. - off-flavour associated with changes in fat oxidation; other/strange f. - other sensation, out of the list. Texture: juiciness - perception of the amount of water released by the product; hardness - basic quality of texture. Overall quality - the general impression of sensory quality based on all tested attributes

control product became darker, whereas the colour of marinated products (AW and SM) became brighter. Rubio et al. (2006) observed reduction of L* parameter by approx. 1.97 during 210-day storage of vacuum-packed dry beef. The value of parameter a* which was a measure of the share of colour from green (values below zero) to red (values above zero), slightly changed depending on the technological procedures.

Table 2. Colour parameters of ripening eye round examined during storage period (60 days)

\begin{tabular}{ccccc}
\hline Colour parameters & $\begin{array}{c}\text { Time } \\
\text { days }\end{array}$ & C & AW & SM \\
\hline L* $^{*}$ & 0 & $38.25 \pm 1.81$ & $38.36 \pm 2.12$ & $39.00 \pm 1.37$ \\
& 60 & $34.07 \pm 0.75$ & $41.29 \pm 1.14$ & $41.52 \pm 4.46$ \\
$\mathrm{a}^{*}$ & 0 & $11.09 \pm 0.80$ & $12.76 \pm 0.74$ & $10.06 \pm 0.70$ \\
& 60 & $9.29 \pm 0.73$ & $10.07 \pm 2.01$ & $8.32 \pm 1.18$ \\
$\mathrm{~b}^{*}$ & 0 & $6.72 \pm 0.83$ & $11.84 \pm 1.40$ & $10.84 \pm 4.37$ \\
\hline
\end{tabular}

Explanatory notes: $\mathrm{C}$ - control with sea salt (3\%), AW - experimental with acid whey and sea salt (3\%), SM - experimental with set milk and sea salt (3\%), mean value \pm standard error. 
The highest parameter $a^{*}$ value was observed in a sample marinated in acid whey (12.74), whereas the lowest in the sample marinated in set milk (10.06). During storage, decrease in colour parameter $\mathrm{a}^{*}$ in samples $\mathrm{C}$ and AW was observed. Similarly, reduced share of red colour in general colour tone was noted by Gök et al. (2008). Decrease of parameter a* was probably related to the ongoing oxidative changes in myoglobin due to lipid oxygenation (increase of the redox potential and TBARS). Values of parameter a* which ranged from 9.00 to 13.25 were observed by Rubio et al. (2006) in vacuum-packed dried beef stored for 210 days. The authors detected decreased share of red colour in general colour tone by approx. 4.25 units during storage of smoked meet.

Applied technology allows for obtaining meat products with desired taste and smell profile. Sensory evaluation revealed that application of acid whey or set milk as a marinade in production of organic ripening beef enhances the feeling of good smell and sour taste which result from correctly conducted fermentation and ripening processes. Analysis of taste and smell profiles of ripening eye round proved that tested samples were characterised by low intensity of negative sensory features, such as: taste and smell of raw meat, rancid taste and smell and other/strange taste and smell. Conducted sensory evaluation revealed that application of acid whey and set milk as marinade did not significantly affect the taste and smell profile of ripening eye round. All samples had comparable general sensory quality within the range from 5.8 to 6.3 c.u.

Higher intensity of feeling bitter taste was observed in the case of the samples marinated in acid whey (2.1 c.u.) in comparison to other samples ( 0.5 c.u.). All evaluated products had similar intensity of bitter taste - approx. 0.5 c.u. Bitter taste related to presence of free amino acids, such as: valine, methionine, isoleucine, phenylalanine and arginine, as well as peptides (Ottinger et al., 2003) may be intensified due to ongoing proteolysis processes (Okoń and Dolatowski, 2014). In studies on the influence of probiotic bacteria strains on the free amino acids profile and sensory factors, Okoń and Dolatowski (2014) observed that the intensity of bitter taste did not correspond with the percentage share of bitter amino acids in the tested product. The assessment of general quality of ripening beef revealed that all samples had good sensory quality (values above 6 c.u.). It may be concluded that application of acid whey and set milk as a marinade positively influences the taste and smell profile of model ripening eye round.

Health safety in microbiological terms can be defined as the absence of pathogenic organisms and toxins of microbiological origin in a specified quantity of food. It must be absolutely ensured as regards meat

Table 3. Amount of lactic acid bacteria and selected pathogenic bacteria in ripening eye round examined during storage period (60 days)

\begin{tabular}{|c|c|c|c|c|c|c|}
\hline \multirow[b]{2}{*}{ Sample } & \multirow{2}{*}{$\begin{array}{l}\text { Time } \\
\text { days }\end{array}$} & \multicolumn{5}{|c|}{$\mathrm{Log}, \mathrm{cfu} / \mathrm{g}$} \\
\hline & & LAB & Clostridium sp. & $\begin{array}{c}\text { Yersinia } \\
\text { enterocolitica }\end{array}$ & $\begin{array}{c}\text { Listeria } \\
\text { monocytogenes }\end{array}$ & $\begin{array}{c}\text { Staphylococcus } \\
\text { aureus }\end{array}$ \\
\hline \multirow[t]{2}{*}{$\mathrm{C}$} & 0 & 6.8 & $<10$ & ND & $<10$ & $<10$ \\
\hline & 60 & 7.2 & $<10$ & ND & $<10$ & $<10$ \\
\hline \multirow[t]{2}{*}{ AW } & 0 & 6.9 & $<10$ & ND & $<10$ & $<10$ \\
\hline & 60 & 7.3 & $<10$ & ND & $<10$ & $<10$ \\
\hline \multirow[t]{2}{*}{ SM } & 0 & 6.7 & $<10$ & ND & $<10$ & $<10$ \\
\hline & 60 & 6.7 & $<10$ & ND & $<10$ & $<10$ \\
\hline
\end{tabular}

Explanatory notes: $\mathrm{C}$ - control with sea salt (3\%), AW - experimental with acid whey and sea salt (3\%), SM - experimental with set milk and sea salt (3\%); ND - not detected. 
products preserved with use of traditional methods (lowering of $\mathrm{pH}$ and $\mathrm{a}_{\mathrm{w}}$, addition of sodium chloride) with exclusion of sodium / potassium nitrate (III)/(V). Microbiological analysis revealed that the number of LAB bacteria was observed at a level of $6.8 \mathrm{cfu} / \mathrm{g}$ in the control sample $(\mathrm{C})$.

On the other hand, in the case of experimental ripening eye round marinated in acid whey, larger amount of LAB was revealed on average at a level of $6.9 \mathrm{cfu} / \mathrm{g}$. During cold storage of the vacuum-packed samples, the number of bacteria increased by almost entire logarithmic rank in all samples. Similar results were observed in ripening pork sausages with addition of acid whey (Wójciak et al., 2015). Information contained in the literature indicate that the number of lactic acid bacteria in ripening beef products is similar to the values obtained in this study and amounts respectively from $6.01 \mathrm{log} \mathrm{cfu} / \mathrm{g}$ to $7.89 \mathrm{log} \mathrm{cfu} / \mathrm{g}$ (Aksu and Kaya, 2002; Kaban, 2013; Kaban and Kaya, 2006) and from $4.57 \mathrm{log} \mathrm{cfu} / \mathrm{g}$ to $6.44 \mathrm{log} \mathrm{cfu} / \mathrm{g}$ for cured dried beef - Cecina de León stored for 60 days in vacuumtight packaging (Rubio et al., 2006; 2007). Presence of any examined pathogenic bacteria: Clostridium sp., L. monocytogenes, $Y$. enterocolitica, S. aureus was not revealed in meat products directly after ripening and after storing of the samples. LAB effectively suppressed the development of pathogenic bacteria which provided biological stabilisation of the product during storage.

Nutritional value of beef is determined by content and composition of protein and intramuscular fat (Kołczak, 2008).

Studies revealed that intramuscular fat of ripening beef is composed approximately of $45 \%$ of saturated fatty acids (SFA), $51 \%$ of monounsaturated fatty acids (MUFA) and $4 \%$ of polyunsaturated fatty acids (PUFA). Acids 14:0, 16:0 and 18:0 are dominant in ripening beef. Oleic acid $(18: 1 \mathrm{n}-9)$ is the predominant MUFA in the product. Linoleic (18:2) and linolenic (18:3) are the predominant PUFAs in beef. Marino et al. (2015) observed similar share of saturated fatty acids (42.06\%) in ripening bresaola - a salted beef ham. At the same time, authors noted in the product less MUFA (39.44\%) and more PUFA (18.81\%) in general amount of fatty acids in comparison to values obtained in our studie. This may be connected with other breed or feeding method. In the analysis of healthy properties of meat products, it is important to determine the relation between PUFA $\omega-6$ to PUFA $\omega-3$ of the fatty acids. Usually, in the case of ripening meat products the relation $\omega-6$ to $\omega-3$ falls within the range from 8 to 14 . The nutritional quality of fat is determined by two additional indexes: atherogenic (AI) and thrombogenic (TI). Their values indicate dietetic value of lipids and their potential effect on development of coronary artery disease in people. Lower atherogenic index was observed in samples marinated with acid whey and set milk in comparison to the control sample. In the case of thrombogenic index, control sample has more favourable value of the index.

Application of acid whey and set milk as a marinade in manufacturing of traditional ripening beef products is a technologically interesting solution. Obtained results prove that appropriately prepared traditional technology of ripening products implemented in the area of Podkarpacie allows to obtain meat products without nitrate and with high microbiological and sensory quality.

\section{CONCLUSIONS}

1. Eye round marinated in acid whey was characterised by increased share of red colour in general colour tone, as well as increased oxidative stability of the product during storage.

2. Application of acid whey as a marinade in production of beef meat also increased the content of polyunsaturated fatty acids (PUFA) in the product.

3. All model products had high content of lactic acid bacteria and there was no pathogenic bacteria such as: L. monocytogenes, Y. enterocolitica, S. aureus, Clostridium sp.

Application of acid whey and set milk as a marinade in manufacturing of traditional ripening beef products leads to production of interesting meat product widely accepted by the consumers. It may be assumed that stage proposed in manufacturing process consisting in marinating meat in acid whey and set milk leads to increased oxidative and microbiological stability of the product and extends its storage stability. Marinating beef in acid whey and set milk eliminates the necessity to add starter cultures in production of ripening products. 
Wójciak, K. M., Krajmas, P., Solska, E., Dolatowski, Z. J. (2015). Application of acid whey and set milk to marinate beef with reference to quality parameters and product safety. Acta Sci. Pol. Technol. Aliment., 14(4), 293-302. DOI: 10.17306/J.AFS.2015.4.30

Table 4. Content of fatty acids in ripening eye round, $\%$ of total fatty acids

\begin{tabular}{|c|c|c|c|c|c|c|}
\hline \multirow{2}{*}{ Name of the fatty acid } & \multicolumn{2}{|c|}{$\mathrm{C}$} & \multicolumn{2}{|c|}{ AW } & \multicolumn{2}{|c|}{ SM } \\
\hline & $\%$ & SD & $\%$ & SD & $\%$ & SD \\
\hline $\mathrm{C} 12: 0$ & 0.06 & 0.00 & 0.11 & 0.01 & 0.07 & 0.00 \\
\hline $\mathrm{C} 13: 0$ & ND & - & 0.08 & 0.00 & ND & - \\
\hline $\mathrm{C} 14: 0$ & 2.47 & 0.01 & 1.88 & 0.01 & 2.00 & 0.01 \\
\hline C14:1 & 0.97 & 0.00 & 0.42 & 0.00 & 0.45 & 0.00 \\
\hline C15:0 & 0.30 & 0.00 & 0.41 & 0.00 & 0.44 & 0.01 \\
\hline C15:1 & ND & - & ND & - & 0.06 & 0.00 \\
\hline C16:0 & 28.28 & 0.01 & 24.16 & 0.05 & 24.71 & 0.16 \\
\hline C16:1 & 4.51 & 0.00 & 2.83 & 0.00 & 3.13 & 0.01 \\
\hline $\mathrm{C} 17: 0$ & 0.80 & 0.00 & 1.14 & 0.00 & 1.39 & 0.00 \\
\hline $\mathrm{C} 17: 1$ & 0.81 & 0.00 & 0.88 & 0.00 & 1.09 & 0.01 \\
\hline C18:0 & 11.52 & 0.01 & 16.83 & 0.02 & 16.99 & 0.05 \\
\hline $\mathrm{C} 18: \ln 9 \mathrm{c}+\mathrm{C} 18: \ln 9 \mathrm{t}$ & 47.76 & 0.00 & 43.12 & 0.04 & 44.58 & 0.27 \\
\hline $\mathrm{C} 18: 2 \mathrm{n} 6 \mathrm{c}+\mathrm{C} 18: 2 \mathrm{n} 6 \mathrm{t}$ & 1.59 & 0.01 & 5.64 & 0.00 & 3.77 & 0.01 \\
\hline C18:3n6 (gamma) & 0.05 & 0.00 & 0.08 & 0.00 & 0.09 & 0.00 \\
\hline C18:3n3 (alpha) & 0.18 & 0.00 & 0.55 & 0.01 & 0.33 & 0.00 \\
\hline C20:0 & 0.09 & 0.00 & 0.14 & 0.00 & 0.12 & 0.00 \\
\hline C20:1 & 0.30 & 0.00 & 0.41 & 0.00 & 0.31 & 0.00 \\
\hline C20:2 & ND & - & 0.14 & 0.00 & 0.10 & 0.00 \\
\hline $\mathrm{C} 21: 0$ & 0.15 & 0.01 & 0.84 & 0.00 & 0.22 & 0.00 \\
\hline $\mathrm{C} 22: 0$ & ND & - & 0.08 & 0.00 & ND & - \\
\hline $\mathrm{C} 22: 2$ & ND & - & 0.08 & 0.00 & ND & - \\
\hline $\mathrm{C} 24: 0$ & ND & - & 0.06 & 0.00 & 0.07 & 0.00 \\
\hline$\Sigma$ SFA & \multicolumn{2}{|c|}{43.65} & \multicolumn{2}{|c|}{45.72} & \multicolumn{2}{|c|}{46.00} \\
\hline$\Sigma$ MUFA & \multicolumn{2}{|c|}{54.35} & \multicolumn{2}{|c|}{47.66} & \multicolumn{2}{|c|}{49.61} \\
\hline$\Sigma$ PUFA & \multicolumn{2}{|c|}{1.82} & \multicolumn{2}{|c|}{6.49} & \multicolumn{2}{|c|}{4.29} \\
\hline$\omega-3$ & \multicolumn{2}{|c|}{0.18} & \multicolumn{2}{|c|}{0.55} & \multicolumn{2}{|c|}{0.33} \\
\hline$\omega-6$ & \multicolumn{2}{|c|}{1.64} & \multicolumn{2}{|c|}{5.72} & \multicolumn{2}{|c|}{3.86} \\
\hline$\omega-6 / \omega-3$ & \multicolumn{2}{|c|}{9.1} & \multicolumn{2}{|c|}{10.4} & \multicolumn{2}{|c|}{11.7} \\
\hline PUFA/SFA & \multicolumn{2}{|c|}{0.04} & \multicolumn{2}{|c|}{0.14} & \multicolumn{2}{|c|}{0.08} \\
\hline AI & \multicolumn{2}{|c|}{0.68} & \multicolumn{2}{|c|}{0.59} & \multicolumn{2}{|c|}{0.61} \\
\hline TI & \multicolumn{2}{|c|}{1.49} & & & & \\
\hline
\end{tabular}

Explanatory notes: $\mathrm{C}$ - control with sea salt (3\%), AW - experimental with acid whey and sea salt (3\%), SM - experimental with set milk and sea salt (3\%); ND - not detected; $\mathrm{SE}$ - standard error; $\mathrm{AI}-$ atherogenic index $=(\mathrm{C} 12: 0+4 \times \mathrm{C} 14: 0+\mathrm{C} 16: 0) /[\mathrm{MUFA}$ + PUFA $(\omega-3)$ and $(\omega-6)]$; TI - thrombogenic index $=(\mathrm{C} 14: 0+\mathrm{C} 16: 0+\mathrm{C} 18: 0) /[(0.5 \times$ MUFA $+0.5 \times$ PUFA $(\omega-6)+3 \times$ PUFA $(\omega-3) /(\omega-6)]$ 
Wójciak, K. M., Krajmas, P., Solska, E., Dolatowski, Z. J. (2015). Application of acid whey and set milk to marinate beef with reference to quality parameters and product safety. Acta Sci. Pol. Technol. Aliment., 14(4), 293-302. DOI: 10.17306/J.AFS.2015.4.30

\section{REFERENCES}

Ahn, D. U., Nam, K. C. (2003). Effect of ascorbic acid and antioxidants on color. lipid oxidation and volatiles of irradiated ground beef. Radiat. Phys. Chem., 71, 149-154.

Aksu, M., Kaya, M. (2002). Effect of commercial starter cultures on the fatty acid composition of pastirma (Turkish dry meat product). J. Food Sci., 67(6), 2342-2345.

Chouliara, E., Badeka, A., Savvaidis, L., Kontominas, M. G. (2008). Combined effect of irradiation and modified atmosphere packaging on shelf-life extension of chicken breast meat: microbiological, chemical and sensory changes. J. Eur. Food Res. Technol., 226 (4), 877-888.

Gök, V., Obuz, E., Akkaya, L. (2008). Effects of packaging method and storage time on the chemical, microbiological, and sensory properties of Turkish pastirma - a dry cured beef product. Meat Sci., 80, 335-344.

Folch, J., Lees, M., Stanley, G. G. S. (1957). A simple metod for the isolation and purification of total lipides from animal tissues. J. Biol. Chem., 226, 497-509.

Hunt, R. G. W. (1987). Measuring colour. Chichester, UK: Ellis Horwood.

Kaban, G. (2013). Sucuk and pastirma: Microbiological changes and formation. Meat Sci., 95, 912-918.

Kaban, G., Kaya, M. (2006). Pastirmadan katalaz pozitif koklarin izolasyonu ve identifikasyonu. Türkiye 9. Gtda Kongresi, 24-25 Mayis, Bolu.

Kołczak, T. (2008). Jakość wołowiny [Beef quality]. Żywn. Nauka Techn. Jakość, 1(56), 5-22 [in Polish].

Laureati, M., Buratti, S., Giovanelli, G., Corazzin, M., Lo Fiego, D. P., Pagliarini, E. (2014). Characterization and differentiation of Italian Parma, San Daniele and Toscano dry-cured hams: a multi-disciplinary approach. Meat Sci., 96 (1), 288-294.

Marino, R., Albenzio, M., della Malva, A., Muscio, A., Sevi, A. (2015). Nutritional properties and consumer evaluation of donkey bresaola and salami: Comparison with conventional products. Meat Sci., 101, 19-24.

Nakajima, H., Inoue, M., Mori, T., Itoh, K.-I., Arakowa, E., Watanabe, H. (1991). Detection and identification of Yersinia pseudotuberculosis and pathogenic Yersinia enterocolitica by an improved polymerase chain reaction method. J. Clin. Microbiol., 30, 2484-2486.

Okoń, A., Dolatowski, Z. J. (2014). Wpływ bakterii probiotycznych na profil wolnych aminokwasów i cechy sensoryczne polędwic wieprzowych surowo dojrzewających podczas przechowywania [Effect of probiotic bacteria on free amino acid profile and sensory traits of raw-ripening pork sirloin during storage]. Żywn. Nauka Techn. Jakość, 3(94), 92-107 [in Polish].

Ottinger, H., Soldo, T., Hofmann, T. (2003). Discovery and structure determination of a novel maillard derived sweetness enhancer by application of the comparative taste dilution analysis (cTDA). J. Agric. Food Chem., 51, 1035-1041.

Pikul, J., Leszczyński, D. E., Kummerow, F. A. (1989). Evaluation of three modified TBA methods for measuring lipid oxidation in chicken meat. J. Agric. Food Chem., 37, 1309.

PN-ISO 15214:2002. Mikrobiologia żywności i pasz - Horyzontalna metoda oznaczania liczby mezofilnych bakterii fermentacji mlekowej - Metoda płytkowa w temperaturze 30 stopni C [Microbiology of food and animal feeding stuffs. Horizontal method for the enumeration of mesophilic lactic acid bacteria. Colony - count technique at $30^{\circ} \mathrm{C}$; in Polish].

PN-ISO 6888-2:2001/A1:2004. Mikrobiologia żywności i pasz - Horyzontalna metoda oznaczania liczby gronkowców koagulazo-dodatnich (Staphylococcus aureus i innych gatunków) - Część 2: Metoda z zastosowaniem pożywki agarowej z plazmą króliczą i fibrynogenem [Microbiology of food and animal feeding stuffs - Horizontal method for the enumeration of coagulase-positive staphylococci (Staphylococcus aureus and other species) - Part 2: Technique using rabbit plasma fibrinogen agar medium; in Polish].

PN-ISO 13299.2. 1998. Analiza sensoryczna. Metodologia. Wytyczne ogólne [Sensory analysis - methodology general guidance for establishing a sensory profile; in Polish].

PN-ISO 11035:1999. Analiza sensoryczna. Identyfikacja i wybór deskryptorów do ustalania profilu sensorycznego z użyciem metod wielowymiarowych [Sensory analysis - Identification and selection of descriptors for establishing a sensory profile by a multidimensional approach; in Polish].

PN-ISO 8586-2:1996. Analiza sensoryczna - Ogólne wytyczne wyboru, szkolenia i monitorowania oceniających - Eksperci [Sensory analysis. General guidance for the selection, training and monitoring of assessors part II experts; in Polish].

PN-ISO 5509:1996. Oleje i tłuszcze roślinne oraz zwierzęce. Przygotowanie estrów metylowych kwasów thuszczowych [Animal and vegetable fats and oils - Preparation of methyl esters of fatty acids; in Polish].

PN-ISO 5508:1996. Oleje i tłuszcze roślinne oraz zwierzęce. Analiza estrów metylowych kwasów tłuszczowych [Animal and vegetable fats and oils - Analysis by gas chromatography of methyl esters of fatty acids; in Polish].

Rubio, B., Martínez, B., González-Fernández, C., García-Cachán, M. D., Rovira, J., Jaime, I. (2006). Influence of storage period and packaging method on sliced dry cured beef "Cecina de león": Effects on microbiological, physicochemical and sensory quality. Meat Sci., 74, 710-717. 
Wójciak, K. M., Krajmas, P., Solska, E., Dolatowski, Z. J. (2015). Application of acid whey and set milk to marinate beef with reference to quality parameters and product safety. Acta Sci. Pol. Technol. Aliment., 14(4), 293-302. DOI: 10.17306/J.AFS.2015.4.30

Rubio, B., Martínez, B., González-Fernández, C., García-Cachán, M. D., Rovira, J., Jaime, I. (2007). Effect of modified atmosphere packaging on the microbiological and sensory quality on a dry cured beef product: "Cecina de león”. Meat Sci., 75, 515-522.

Sip, A., Więckowicz, M., Olejnik-Schmidt, A., Grajek, W. (2012). Anti-listeria activity of lactic acid bakteria isolated from golka, a regional cheese produced in Poland. Food Control, 26, 117-124.

Węsierska, E., Szołtysik, M., Migdał, W. (2014). The properties of fermented blef products ripened as entire promil cuts of $M$. semitendinosus, $M$. semimembranosus and MM. psoas major and minor. Ann. Anim. Sci., 14, 1, 197-212.
Węsierska, E., Szołtysik, M., Palka, K., Lipczyńska, A., Lipczyńska-Szlaur, E. (2013a). Physico-chemical, biochemical and microbiological changes of Kumpia wieprzowa during ripening. Brit. Food J., 115, 8, 1187-1196.

Węsierska E., Palka K., Bogdańska J., Chabior K., Barwińska E. (2013b). Sensory quality of selected raw ripened meat products. Acta Sci. Pol., Technol. Aliment., 12(1), 41-50.

Wójciak, K. M., Dolatowski, Z. J., Kołożyn-Krajewska, D. (2015). Use of acid whey and probiotic strains to improve microbiological quality and sensory acceptance of organic fermented sausage. J. Food Process. Pres. DOI:10.1111/jfpp.12259.

QMP_504_EC_27_51_1. Liczba Listeria monocytogenes. Metoda płytkowa - posiew powierzchniowy.

\section{ZASTOSOWANIE SERWATKI KWASOWEJ I MLEKA ZSIADŁEGO DO MARYNOWANIA WOŁOWINY W ODNIESIENIU DO JAKOŚCI I BEZPIECZEŃSTWA PRODUKTU}

\section{STRESZCZENIE}

Wstęp. Celem badań była ocena możliwości zastosowania serwatki kwasowej oraz mleka ukwaszonego jako marynaty w produkcji ligawy dojrzewającej.

Materiał i metody. Badania obejmowały oznaczenie wartości $\mathrm{pH}$, aktywności wody, potencjału oksydacyjno-redukcyjnego, wskaźnika TBARS, parametrów barwy w systemie CIE L*, a*, b*, a także oznaczanie liczby bakterii kwasu mlekowego i wybranych bakterii patogennych po procesie dojrzewania oraz po sześćdziesięciodniowym okresie przechowywania chłodniczego. Analizę sensoryczną oraz analizę profilu kwasów tłuszczowych przeprowadzono po zakończeniu procesu dojrzewania.

Wyniki. Analiza wartości pH w wyrobach wykazała, że zastosowanie serwatki kwasowej do marynowania wołowiny wpłynęło na wzrost kwasowości ligawy dojrzewającej $(5,14)$. Najwyższą wartość parametru a* barwy po dojrzewaniu oraz podczas przechowywania ligawy obserwowano w próbie $\mathrm{S}$ (odpowiednio 12,76 i 10,07), najniższą zaś w próbie Z (odpowiednio 10,06 i 7,88). W ligawie marynowanej w serwatce kwasowej stwierdzono wyższą o ok. 4\% zawartość kwasów tłuszczowych wielonienasyconych (PUFA) w porównaniu z pozostałymi próbami.

Wnioski. Zastosowanie serwatki kwasowej do marynowania wołowiny wpłynęło na zwiększenie udziału barwy czerwonej w ogólnym tonie barwy oraz zwiększenie stabilności oksydacyjnej produktu w trakcie przechowywania. Wykorzystanie serwatki kwasowej oddziaływało na wzrost zawartości wielonienasyconych kwasów tłuszczowych (PUFA) w produkcie. Wszystkie produkty modelowe charakteryzowały się dużą zawartością bakterii kwasu mlekowego oraz absencją bakterii patogennych takich, jak: L. monocytogenes, Y. enterocolitica, S. aureus, Clostridium sp.

Słowa kluczowe: serwatka kwasowa, wołowina, ekologiczne wyroby mięsne

Received - Przyjęto: 20.07.2015

Accepted for print - Zaakceptowano do druku: 14.09.2015

For citation - Do cytowania

Wójciak, K. M., Krajmas, P., Solska, E., Dolatowski, Z. J. (2015). Application of acid whey and set milk to marinate beef with reference to quality parameters and product safety. Acta Sci. Pol. Technol. Aliment., 14(4), 293-302. DOI: 10.17306/J.AFS.2015.4.30 